УДК 657.471

\title{
ТЕОРЕТИЧНІ АСПЕКТИ ПОБУДОВИ ОБЛІКУ ВИТРАТ НА ВИРОБНИЦТВО ПРОДУКЦІї РОСЛИННИЦТВА
}

\section{THEORETICAL ASPECTS OF COST ACCOUNTING FOR CROP PRODUCTION}

\author{
Сухоносенко Інна Ігорівна \\ здобувач вищої освіти, \\ Запорізький національний університет \\ ORCID: https://orcid.org/0000-0002-8326-4735 \\ Гринь Вікторія Петрівна \\ кандидат економічних наук, доцент, \\ Запорізький національний університет \\ ORCID: https://orcid.org/0000-0002-6758-7374
Sukhonosenko Inna, Gryn Viktoriia
Zaporizhia National University

\begin{abstract}
У статті сформовано ключові завдання обліку витрат на виробництво сільськогосподарської продукції, які в основі полягають в управлінні витратами й контролі за виробничою діяльністю на її здійснення. Досліджено процес організації обліку витрат виробництва на сільськогосподарському підприємстві, як систему взаємодії всіх ключових ланок підприємства. З'ясовано комплекс особливостей рослинництва як галузі сільського господарства, та досліджено процес виробництва на аграрних підприємствах з врахуванням особливостей ресурсного забезпечення та його обмеженості. Сфрормована економічна сутність витрат, яка проявляється у формуванні сукупного продукту, а його вартість формується з вартості використаних засобів виробництва, перенесеної на продукцію, що виробляють, і знову створеної вартості. Систематизовано основні принципи організації обліку витрат на сільськогосподарському підприємстві, та розкрито їх зміст. Сорормовано практичні аспекти обліку витрат і калькулювання собівартості сільськогосподарської продукції. Розкритого головні завдання обліку витрат на виробництво сільськогосподарської продукції рослинництва. Запропоновано витрати на виробництво сільськогосподарської продукції рослинництва розглядати водночас об'єктами управління та управлінського обліку. Висвітлено актуальні питання збільшення обсягу виробництва продукції рослинництва та поліпшення її якості. Наведено характеристику обліку витрат виробництва продукції рослинництва й обліку групування за статтями. Акцентовано увагу на чинники, на які підприємство не має впливу, а вони й досі є невирішеними - неврегульованість товарного ринку, а саме продаж продукції та налагодження системи матеріального стимулювання виробництва певної продукції за аналогією 3 розвиненими країнами, зокрема з ЄС. Наголошено, що обмежене використання схожих можливостей сільськогосподарськими виробниками в сучасних умовах неприпустима. 3'ясовано, що на вітчизняних аграрних підприємств суттєве підвищення ролі бухгалтерського обліку як основного засобу одержання достовірної, коректної, правдивої інфрормації для прийняття економічно рішень і прогнозування ризику у виробничо-фрінансовій діяльності сільськогосподарського підприємства підпорядковується організації.

Ключові слова: витрати, виробництво, організація, продукція рослинництва, облік, управління, ресурси, сільськогосподарська продукція.
\end{abstract}

В статье ссрормирован ключевые задачи учета затрат на производство сельскохозяйственной продукции, в основе заключаются в управлении затратами и контроле за производственной деятельностью на ее осуществление. Исследован процесс организации учета издержек производства на сельскохозяйственном предприятии, как систему взаимодействия всех ключевых звеньев предприятия. Выяснено комплекс особенностей растениеводства как отрасли сельского хозяйства, и исследован процесс производства на аграрных предприятиях с учетом особенностей ресурсного обеспечения и его ограниченности. Ссрормирована. экономическая сущность расходов, которая проявляется в формировании совокупного продукта, а его стоимость фрормируется из стоимости использованных средств производства, перенесенной на продукцию производят, и вновь созданной стоимости.

Ключевые слова: расходы, производство, организация, продукция растениеводства, учет, управление, ресурсы, сельскохозяйственная продукция. 
The article formulates the key tasks of accounting for the costs of agricultural production, which are based on cost management and control over production activities for its implementation. The process of organization of accounting for production costs at an agricultural enterprise as a system of interaction of all key parts of the enterprise is studied. The complex of peculiarities of crop production as a branch of agriculture is clarified, and the process of production at agricultural enterprises is investigated, taking into account the peculiarities of resource provision and its limitations. Formed. the economic essence of costs, which is manifested in the formation of the aggregate product, and its value is formed from the value of the means of production used, transferred to the products produced, and the newly created value. The basic principles of the organization of the account of expenses at the agricultural enterprise are systematized, and their maintenance is opened. The practical aspects of cost accounting and costing of agricultural products are formed. The main tasks of accounting for the costs of agricultural production are disclosed. It is proposed to consider the costs of agricultural production of crop products as objects of management and management accounting. Topical issues of increasing the volume of crop production and improving its quality are highlighted. The characteristic of the account of expenses of manufacture of crop production and the account of grouping on articles is resulted. Emphasis is placed on factors that the company has no influence on, and they are still unresolved - the unregulated commodity market, namely the sale of products and the establishment of a system of material incentives for the production of certain products by analogy with developed countries, including the EU. It is emphasized that the limited use of similar opportunities by agricultural producers in modern conditions is unacceptable. It was found that in domestic agricultural enterprises a significant increase in the role of accounting as the main means of obtaining reliable, correct, truthful information for economic decisions and risk forecasting in the production and financial activities of agricultural enterprises is subordinated to the organization.

Keywords: expenses, production, organization, crop production, accounting, management, resources, agricultural products.

Постановка проблеми. Сучасною світовою тенденцією є зростання вартості сільськогосподарської продукції та ії дефріцит в багатьох країнах, що постійно підвищує актуальність збільшення обсягу виробництва продукції рослинництва та поліпшення ії якісних характеристик. Саме тому аграрна галузь в рамках держави є надважливим сектором економіки, а в аграрних підприємств ключовим ресурсом одержання прибутків. Отже облік вважають інорормаційним ресурсом, потрібної для одержання показників для розрахунку витрат з виробництва сільськогосподарської продукції рослинництва, обсягу виробленої сільськогосподарської продукції (наданих робіт чи послуг) у натуральних і грошових одиницях та використання всіх видів виробничих ресурсів та взагалі управління та контролю за економічними показниками. Рослинництво це галузь економіки яка має багато особливостей: вплив природних фракторів; вплив соціальних фракторів. Ці особливості потрібно використати під час організації бухгалтерського обліку. Основне завдання обліку витрат на виробництво сільськогосподарської продукції полягає в управлінні витратами й контролі за виробничою діяльністю на її здійснення.

Аналіз останніх досліджень і публікацій. Дослідженням і визначенням ролі бухгалтерського обліку в системі управління та управлінської спрямованості бухгалтерського обліку займалася велика кількість науковців та вчених, серед яких: Бутинець Ф. Ф., Чижевська Л. В., Герасимчук Н. В. [2], Огійчук М. Ф., Плаксієнко В. Я., Беленкова М. І. [8], та ін. Висновки науковців стосовно вирішення загальнотеоретичних і методичних питань управлінського обліку, а також багатьох галузей промисловості представлені в широкому обсязі. Але дуже вузько розкриті проблеми та недоліки сільськогосподарського виробничого обліку, а саме обліку витрат на виробництво сільськогосподарської продукції рослинництва в аграрних підприємствах, а спричинено це його особливостями, специфікою та природно-економічними умовами виробництва.

Як відмічає Ф. Ф. Бутинець: «сьогодні питання обліку витрат з метою зниження собівартості продукції знаходяться поза увагою керівників підприємства та бухгалтерів. Забезпечити рентабельність роботи підприємства, у першу чергу, прагнуть за рахунок високих відпускних цін, а не за рахунок економії витрат виробничих ресурсів. Однак це ненадійний і безперспективний спосіб вирішення проблем виживання підприємства» [2, с. 308].

Формулювання цілей статті. Мета статті пошук шляхів удосконалення побудови системи обліку витрат у рослинництві на основі тісної взаємодії фрінансового та управлінського обліку на сільськогосподарському підприємстві.

Виклад основного матеріалу дослідження. Інфрормація про витрати потрібна для розрахунку ціни на сільськогосподарську продукцію для того, щоб визначити, який виробничий процес $є$ найбільш економним, який підрозділ використовує ресурси ефективніше, а також для прийняття важливих управлінських і фрінансових рішень. Вітчизняні науковці М. Ф. Огійчук, В. Я. Плаксієнко, М. І. Беленкова та інші вва- 
жають, що побудова системи управлінського обліку на аграрних підприємствах виконує такі кроки: уточнення функцій управлінського обліку та виконавців; фоормування інфрормації про понесені підприємством витрати на операційні потреби, вихід продукції та результати діяльності; здійснення організаційних заходів [8].

Рослинництво як галузь сільського господарства, яка має комплекс особливостей: непрогнозований вплив природних і соціальних фракторів. Основними засобами і предметами праці є обмежені ресурси, такі як земля і живі тварини та рослини. Вагомий вплив мають погодні умови на процес виробництва в сільському господарстві, такі як зливи, посуха, град та інше. Отже ці важливі особливості потрібно врахувати під час організації бухгалтерського обліку. Земля це один із головних засобів виробництва сільськогосподарських підприємств, та ще й обмежені у кількісному виражені, а у промисловості це лише територія, на якому розміщене і знаходиться підприємство. Інші засоби, котрі в процесі виробництва поступово зношуються фрізично та морально і амортизуються, тому через деякий час їх потрібно замінювати новими для подальшого користування, а земля це незмінний, обмежений і невідтворний засіб виробництва. За раціонального використання вона не тільки не зношується, а навпаки - підвищує свою якість та родючість [1]. Виробничий цикл у рослинництві проходить певний період: до одного року (соняшник, зернові культури тощо); кілька років (вирощування багаторічних насаджень). Отже виникає гостра необхідність створити на підприємстві організацію обліку витрат за принципами відповідно до Закону України «Про бухгалтерський облік та фрінансову звітність в Україні» [7].

Потрібно створити на підприємстві організацію обліку витрат за такими принципами (рис. 1).

Стан виробництва має такі особливості: есрективність; ступінь використання досягнень науково-технічного прогресу; місце; роль робітника у виробничому процесі. При обмеженій кількості ресурсів і разом з тим досягнення планової ефективності постає питання постійного співставлення понесених витрат й отриманих результатів. Під впливом інфляції дана проблема суттєво посилюється, а дані про виробничі витрати потрібно щоденно зіставляти 3 майбутніми витратами, що суттєво залежить від впливу зовнішнього середовища [3]. Здатність уникнення або прогнозування впливу великої кількості негативних, внутрішніх і зовнішніх факторів можна досягти завдяки раціонально організованому та ефективному обліку витрат на виробництво.

Витрати на виробництво сільськогосподарської продукції можуть бути показані в натуральній і вартісній вимірах [5, с. 360]. У цілях організації виробничо-господарської діяльності сільськогосподарського підприємства вагоме значення має планування та облік витрат у натуральних одиницях (кількість, маса, об'єм та ін.). Але для оцінки результатів даної діяль-

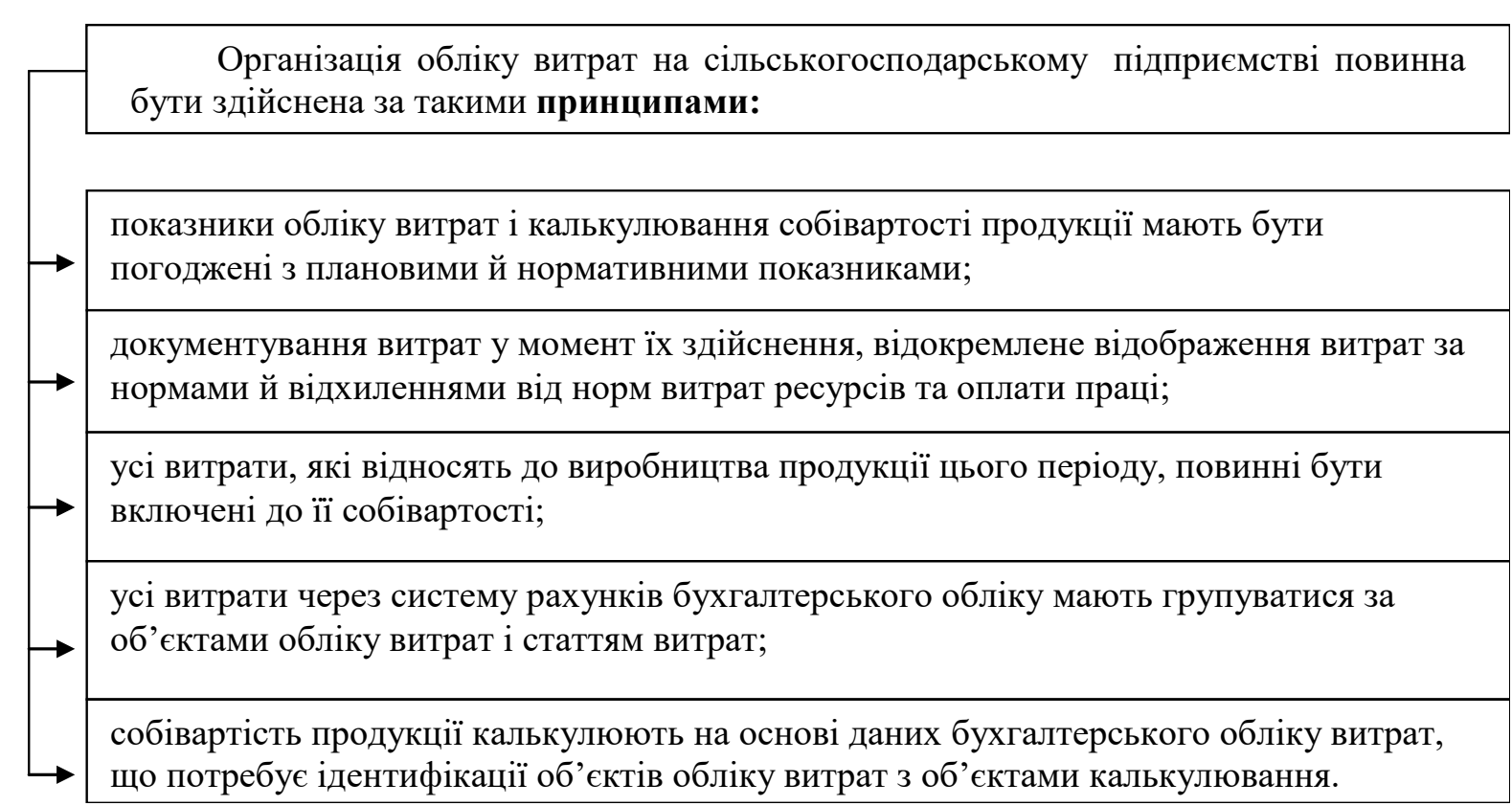

Рис. 1. Принципи організації обліку витрат на сільськогосподарському підприємстві Джерело: згруповано автором за даними [8] 
ності суттєвою є вартісна оцінка витрат, тому що вона придає грошового виразу виготовленій продукції та наданим послугам [8, с. 138].

Отже економічна сутність витрат проявляється у фрормуванні сукупного продукту, а його вартість формується 3 вартості використаних засобів виробництва, перенесеної на продукцію, що виробляють, і знову створеної вартості [9, с. 266].

Отже витрати на виробництво сільськогосподарської продукції в аграрних підприємствах постають як об'єкти управління та управлінського обліку. Аграрні підприємства можна описати за такими характеристиками обліку витрат сільськогосподарської продукції рослинництва як її особливості та етапи, 3 яких цей облік фрормується (рис. 2).

Відповідно до діючого законодавства, керівник повинен створити належні умови для правильного ведення бухгалтерського обліку, забезпечити неухильне виконання всіма підрозділами, цехами, службами та працівниками, причетними до бухгалтерського обліку, правомірних вимог бухгалтера щодо коректного заповнення документів, дотримання порядку офрормлення та вчасного подання первинних документів.

Основною метою обліку витрат на виробництво сільськогосподарської продукції рослинництва аграрних підприємства $€$ вчасне, змістовне, вірогідне, коректне зображення фрактичного розміру й складу витрат і контроль за застосовуванням усіх видів виробничих ресурсів та обсягу виробленої продукції в натуральних і грошових одиницях. Управління витратами охоплює всі сторони виробничих процесів, що здійснюють на сільськогосподарському підприємстві [4, с. 146].

Витрати на виробництво сільськогосподарської продукції рослинництва аграрних підприємств в плануванні й обліку формують за статтями, які господарство фрормулює на свій розсуд й затверджує наказом про облікову політику [6].

Витрати в рослинництві обчислюють за представленими статтями витрат, а саме: на оплату праці; відрахування на соціальні заходи; насіння і посадковий матеріал; добрива; засоби захисту рослин; роботи та послуги; витрати на утримання основних засобів; інші витрати; витрати на організацію виробництва й управління.

Дослідження практичних аспектів обліку витрат і калькулювання собівартості продукції на сільськогосподарських підприємствах показує, що в обліковій системі сільськогосподарського підприємства утворюється інсрор- мація про виробничі витрати за видами сільськогосподарської продукції [6, с. 286].

Головними завданнями обліку витрат на виробництво сільськогосподарської продукції рослинництва $€$ [9]: інфрормаційне забезпечення адміністрації підприємства для прийняття управлінських рішень; спостереження й контроль за фрактичним рівнем витрат порівняно $з$ їх нормативами й плановими розмірами для виявлення відхилень і фрормування економічної стратегії на наступні роки; вірогідний облік виходу продукції за її видами з включенням якості; розрахунку собівартості виробленої продукції для оцінки готової продукції та розрахунку фрінансових результатів; виявлення й оцінка економічних результатів виробничої діяльності структурних підрозділів; систематизація інорормації управлінського обліку виробничої діяльності для прийняття рішень, оскільки вони мають довготривалий характер.

Висновки. Для аграрних підприємств суттєве підвищення ролі бухгалтерського обліку як основного засобу одержання достовірної, коректної, правдивої інфрормації для прийняття економічно рішень і прогнозування ризику у виробничо-срінансовій діяльності сільськогосподарського підприємства підпорядковується організації. Організація обліку витрат на виробництво продукції рослинництва закріплена в Положенні про облікову політику підприємства і є причиною для оформлення витрат і виходу продукції. Отже організація обліку виробничих витрат залежить від багатьох фракторів. На організацію обліку впливають такі фрактори: види діяльності, характер виробництва, структура управління, розмір підприємства, особливості технології й організації виробництва. Можемо вважати що витрати на виробництво сільськогосподарської продукції рослинництва постають водночас об'єктами управління та управлінського обліку. Правильний і ефективний вибір методів обліку витрат з'ясовується завдяки особливостям технологічних процесів і залежить від керівництва та бухгалтерів самого підприємства.

Нині $€$ чинники, які не залежать від підприємства й досі $є$ невирішеними - неврегульованість товарного ринку, а саме продаж продукції та налагодження системи матеріального стимулювання виробництва певної продукції за аналогією з розвиненими країнами, зокрема з $€ С$. Обмежене використання схожих можливостей сільськогосподарськими виробниками в сучасних умовах неприпустима. На даний момент це є суттєвою проблемою для сільськогосподарських підприємств. 


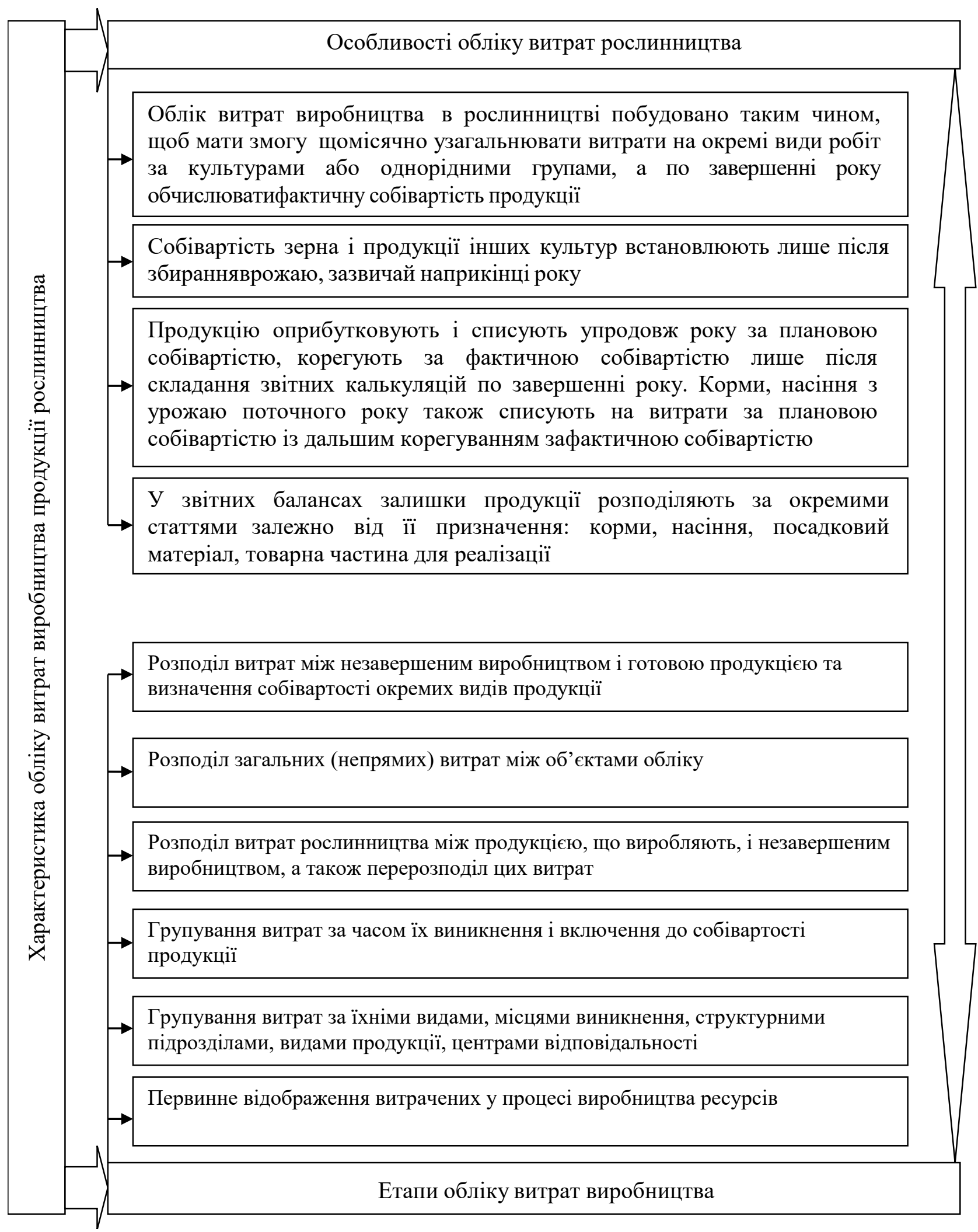

Рис. 2. Оцінка продукції рослинництва за плановою (фактичною) собівартістю Джерело: згруповано автором за даними [8] 


\section{СПИСОК ВИКОРИСТАНИХ ДЖЕРЕЛ:}

1. Біологічні активи : Положення (стандарт) бухгалтерського обліку 30 , затверджене наказом Міністерства фрінансів України № 790 від 18 листопада 2005 p. URL: http://zakon.nau.ua/doc/?doc_id=243748

2. Бутинець Ф.Ф., Чижевська Л.В., Герасимчук Н.В. Бухгалтерський управлінський облік : навч. посібн. Житомир : ЖІTI, 2000. 448 c.

3. Витрати : Положення (стандарт) бухгалтерського обліку 16, затверджене наказом Міністерства фрінансів України № 318 від 31 грудня 1999 р. URL: http://zakon.nau.ua/doc/?code=z0027-00

4. Запаси : Положення (стандарт) бухгалтерського обліку 9, затверджене наказом Міністерства фрінансів України від 20 жовтня 1999 р. № 246. URL: http://www.zakon.rada.gov.ua/go/z0751-99

5. Інструкція про застосування плану рахунків бухгалтерського обліку активів, капіталу, зобов'язань і господарських операцій, затверджена наказом Мінфіну України № 291 від 30 листопада 1999 р. / Верховна Рада України. URL: http://www.rada.gov.ua

6. Методичні рекомендації з планування обліку і калькулювання собівартості продукції (робіт, послуг) сільськогосподарських підприємств, затверджені наказом МАПУ № 132 від 18 травня 2001 р. URL: http://www.rada.gov.ua

7. Методичні рекомендації щодо застосування спеціалізованих форм регістрів журнально-ордерної форми обліку для сільськогосподарських підприємств № 390. URL: http://zakon.rada.gov.ua

8. Огійчук М.Ф., Плаксієнко М.І., Беленкова та ін. Фінансовий та управлінський облік за національними стандартами : підручник / за ред. проф. М.Ф. Огійчука. 6-те вид., перероб. і допов. Київ : Алерта, 2011. 1042 с.

9. Про бухгалтерський облік та фрінансову звітність в Україні : Закон України від 16.07.1999 р. № 996-XIV зі змін. і доп. URL: http://zakon.rada.gov.ua

\section{REFERENCES:}

1. Ministry of Finance of Ukraine (2005) Biolohichni aktyvy: Polozhennya (standart) bukhhalters'koho obliku 30. Available at: http://zakon.nau.ua/doc/?doc_id $=243748$

2. Butynets', F.F., Chyzhevs'ka, L.V. and Herasymchuk, N.V. (2000) Bukhhalters'kyy upravlins'kyy oblik [Managerial accounting]. Zhytomyr: ZhlTI.

3. Ministry of Finance of Ukraine (1999) Vytraty: Polozhennya (standart) bukhhalters'koho obliku 16. Available at: http://www.zakon.rada.gov.ua/go/z0027-00

4. Ministry of Finance of Ukraine (1999) Zapasy: Polozhennya (standart) bukhhalters'koho obliku 9. Available at: http://www.zakon.rada.gov.ua/go/z0751-99

5. Ministry of Finance of Ukraine (1999) Decree of the Ministry of Finance of Ukraine «Instructions on the application of the plan of accounts accounting of assets, capital, liabilities and business operations». Available at: http://www.rada.gov.ua

6. Ministry of Agricultural Policy of Ukraine (2001) Decree of the Ministry of Agricultural Policy of Ukraine «Methodical recommendations on accounting planning and calculation of the cost of product (works, services) the agricultural enterprises». Available at: http://www.rada.gov.ua

7. Ministry of Agricultural Policy of Ukraine (2009) Decree of the Ministry of Agricultural Policy of Ukraine «On the approval of specialized forms of registers journal-order form of accounting for agricultural enterprises and methodic recommendations on their application». Available at: http://zakon.rada.gov.ua

8. Ohiychuk, M.F. (ed.) (2011) Finansovyy ta upravlins'kyy oblik za natsional'nymy standartamy [Financial and management accounting by national standards]. 6nd ed. Kyiv: Alerta.

9. The Verkhovna Rada of Ukraine (1999)The Law of Ukraine «On Accounting and Financial Reporting in Ukraine». Available at: http://zakon.rada.gov.ua/ 